\title{
THE MORPHOLOGY OF BLASTOCYST IMPLANTATION
}

\author{
O. NILSSON \\ Reproduction Research Unit, Biomedical Centre, \\ Box 571, S-751 23 Uppsala, Sweden
}

Implantation is a process whereby the blastocyst becomes embedded in the endometrium. Firstly, the blastocyst must contact the epithelium, then the trophoblast cells will start invading the endometrium. In species with delayed implantation, the blastocyst requires activation before its attachment.

Thus there are three stages involved in delayed implantation: blastocyst activation, trophoblast attachment and trophoblast invasion. The following account indicates what characterizes these three stages at a cellular and subcellular level and what suggestions structural analysis can give as to the mechanisms controlling these processes.

\section{DELAYED IMPLANTATION}

The blastocysts of some mammalian species are normally kept in a state of delay before implantation (Enders, 1963; Lanman, 1970). In some other species, for instance the mouse, a delayed implantation also can be obtained experimentally (Yoshinaga \& Adams, 1966; Humphrey, 1967; Smith \& Biggers, 1968; McLaren, 1971). This offers a biological system appropriate for studies on implantation, since its various stages can be controlled and timed easily. The present results and discussion are mostly concerned with delayed implantation in the mouse, although some references are also given to reports on the rat. It must be noted, however, that implantation in the mouse differs in several ways from that of the rat (for reports on rat implantation, see Warren \& Enders, 1964; Enders \& Schlafke, 1967; Potts \& Psychoyos, 1967a; Tachi, Tachi \& Lindner, 1970; Ljungkvist \& Nilsson, 1971, and on mouse implantation, see Potts, 1966; Finn \& McLaren, 1967; Potts \& Psychoyos, 1967b; Potts \& Wilson, 1967; Reinius, 1967; Potts, 1968; Pollard \& Finn, 1972; Galarco \& Epstein, 1973). Several publications comprehensively cover various aspects of implantation (see Lobel, Levy \& Shelesnyak, 1967; Enders \& Schlafke, 1969; Potts, 1969; Wong \& Dickson, 1969; Hubinont, Leroy, Robyn \& Leleux, 1970; Raspe, 1970; Blandau, 1971).

We have used the technique of Yoshinaga \& Adams (1966), maintaining the blastocysts in the uteri of ovariectomized mice by progesterone treatment until implantation was induced by injecting oestrogen. The mice were killed at various times after oestrogen injection and the uteri were imbedded in Epon and sectioned for light and electron microscopy. Fixation by perfusion and careful handling during the subsequent procedures is necessary to produce reliable morphology. Also scanning electron microscopy has been performed on blastocysts and endometrium after fixation with glutaraldehyde and freezedrying. 


\section{BLASTOCYSTS IN DELAYED IMPLANTATION}

The morphology of implantation delay in the mouse is characterized by luminal closure around the blastocyst (Pl. 1, Figs 1 and 2). However, the degree of contact between trophoblast and uterine epithelium varies. From being a few microns apart during the days following ovariectomy (Pl. 1, Fig. 3 and Pl. 2, Fig. 4), the trophoblast and the uterine epithelium form a closer contact after about a week of progesterone treatment (Pl. 3, Fig. 5). However, after a further week of treatment they separate again but there is always close contact between apical protrusions of the epithelium and the trophoblast (Pl. 4, Fig. 6). These 'morel-like' protrusions grow out from the epithelial surface (Psychoyos \& Mandon, 1971a, b) (Pl. 5, Fig. 7) and leave imprints on the blastocyst (Bergström \& Nilsson, 1973 and Pl. 5, Fig. 8).

The apical protrusions have an amorphous ultrastructure (Pl. 4, Fig. 6), implying an ultrastructurally ill-defined content, such as proteins and amino acids (Nilsson, 1972). The protrusions seem to participate in the nutrition of the blastocyst, since their disappearance is correlated with a decline in

\section{EXPLANATION OF PLATES 1 TO 4}

PLATE 1

FIG. 1. Longitudinal section of the uterus of a mouse in delayed implantation. The uterine lumen is closed and has an irregular course. In the stroma, uterine glands are evident. The blood vessels are empty because fixation was effected by vascular perfusion. A blastocyst is situated in the antimesometrial part of the lumen and its blastocoele appears as a slightly elongated opening of the lumen in the middle of the picture. $\times 50$.

Fig. 2. Mesometrial part of a blastocyst in delay. The closed uterine lumen is seen in the lower part of the picture and the blastocoele in the right upper part. The uterine epithelium contains many basal lipid granules and a row of lipid granules just above the nuclei. $\times 800$. Fig. 3. Part of a 'delayed' blastocyst in the uterus of a mouse after 2 days of progesterone treatment following ovariectomy. The surface of the uterine epithelium possesses microvilli and apical protrusions. The blastocyst is separated from the epithelium by a narrow gap. $\times 7000$.

\section{PLATE 2}

Fig. 4. Part of a 'delayed' blastocyst in the uterus of a mouse after 2 days of progesterone treatment following ovariectomy. The microvilli of the uterine epithelium have an irregular appearance. Several apical vesicles are situated rather close to the epithelial surface. The blastocyst is separated from the uterine surface by a narrow space. The outer border of the trophoblast is irregularly outlined. The cytoplasm of the trophoblast contains glycogen granules. $\times 29,000$.

\section{PLATE 3}

FIG. 5. Part of a 'delayed' blastocyst in the uterus of a mouse after 7 days of progesterone treatment following ovariectomy. The trophoblast is in close contact with the uterine epithelium. At the border, dark deposits are present. Adjacent to the cell surface, the cytoplasm of the uterine epithelium is dense and nearly devoid of organelles and inclusions. The trophoblast possesses mitochondria with spherical excavations and evenly distributed ribosomes. $\times 37,000$.

\section{PLATE 4}

Fig. 6. Part of a 'delayed' blastocyst in the uterus of a mouse after 14 days of progesterone treatment following ovariectomy. Two apical protrusions of the uterine epithelium are seen. They contain a rather homogeneous substance. The trophoblast lies close to the protrusions. Part of an embryoblast is also observed. $\times 10,000$.

Frg. 7. Luminal epithelial surface of the uterus from a rat early on Day 4 of a normal pregnancy. The specimen was obtained during the period of progesterone dominance. The surface of the epithelial cells is slightly bulging. The microvilli and several apical protrusions are observed. $\times 4000$. 
PLATE 1
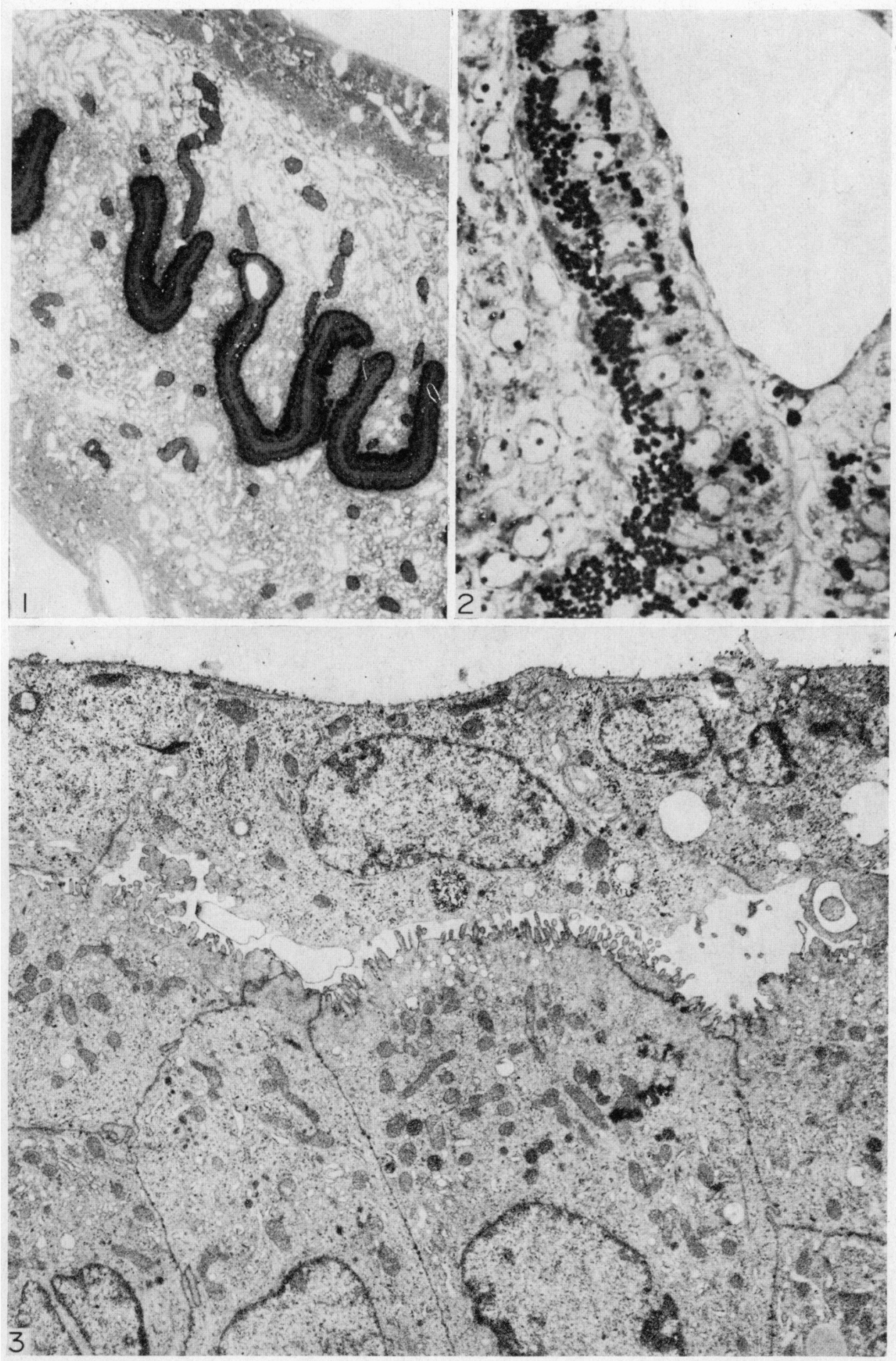
PLATE 2

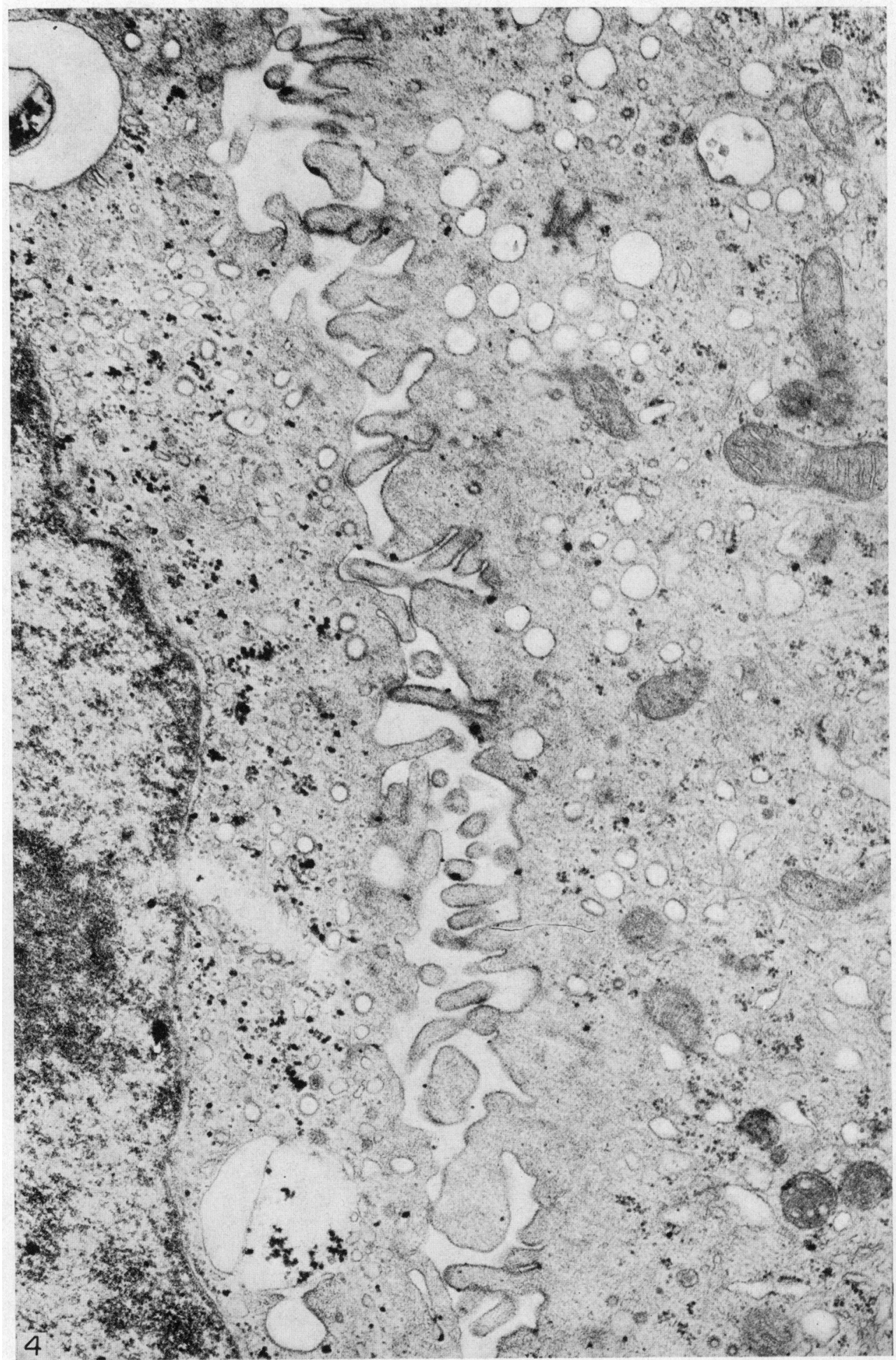


PLATE 3

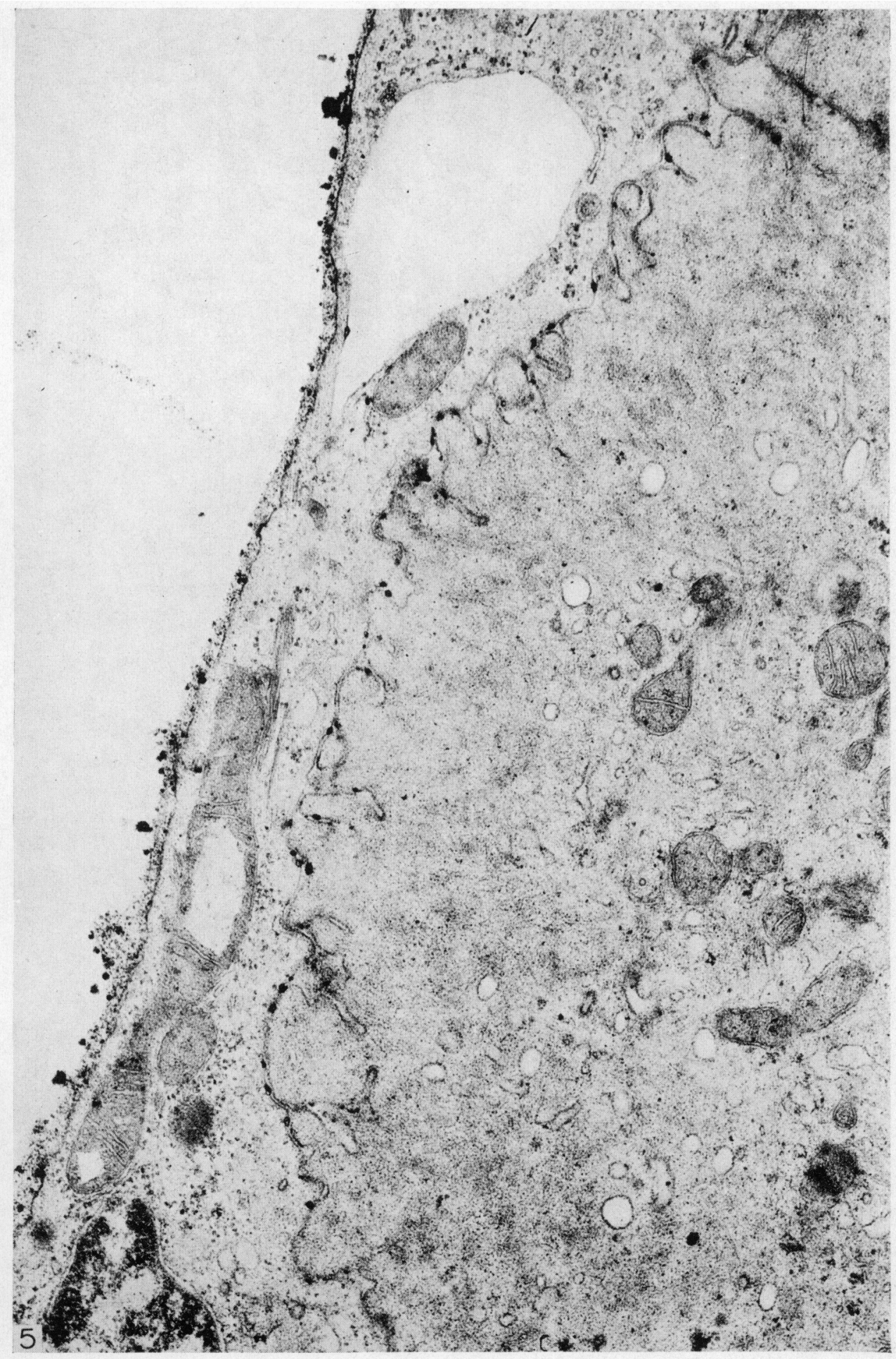




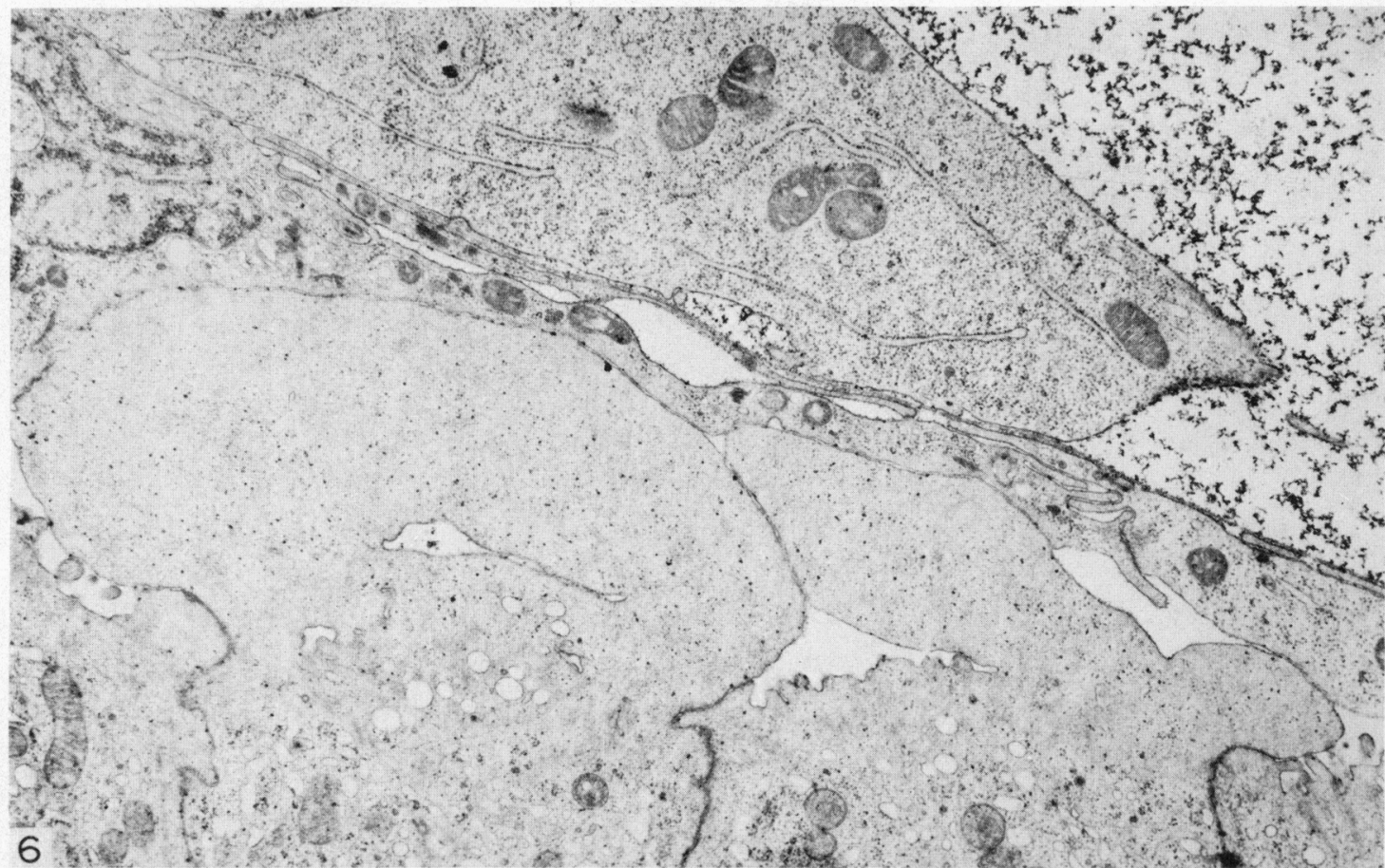

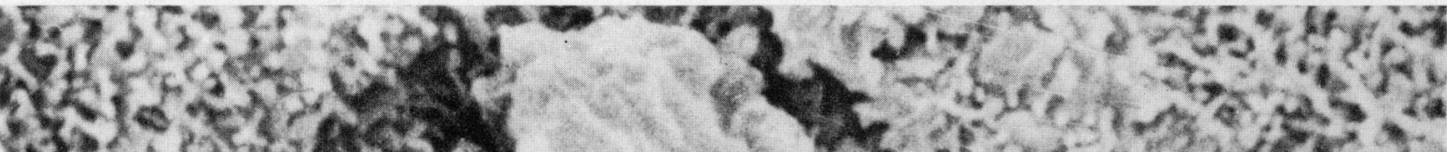
(3) terivos

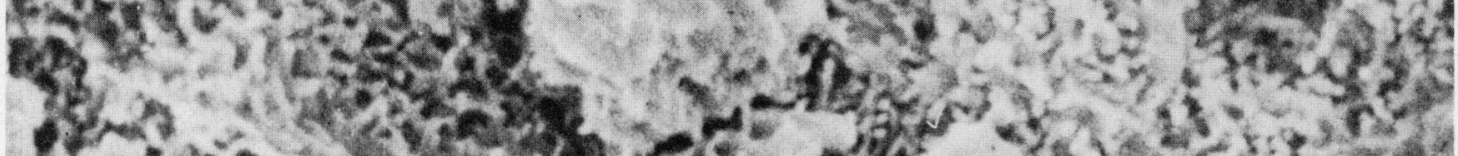

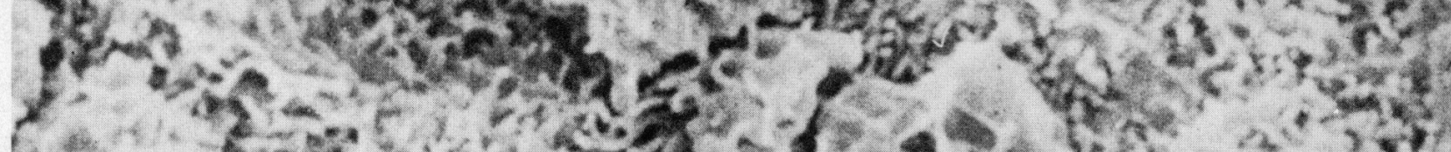

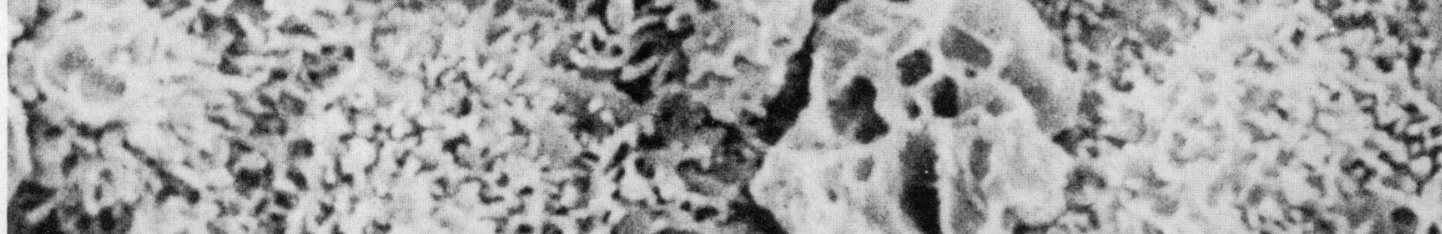

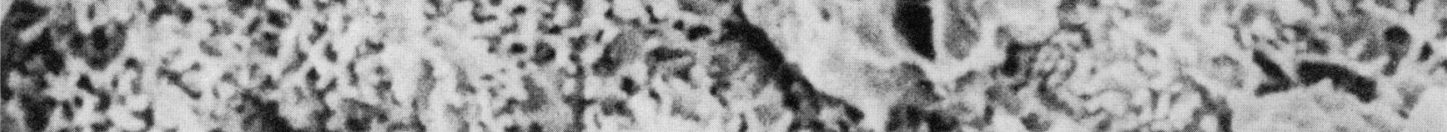

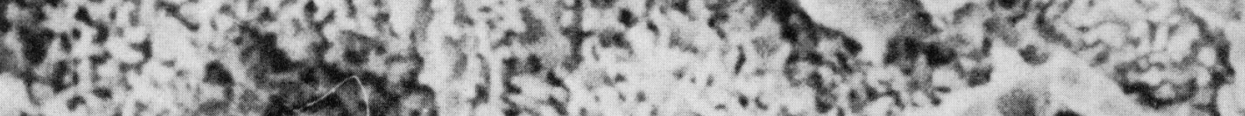
moty 5 .

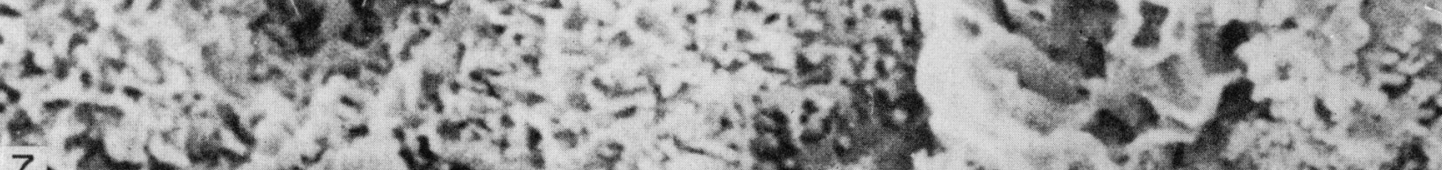

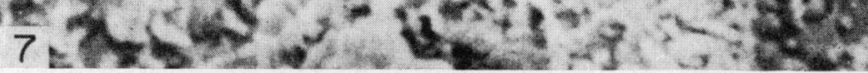




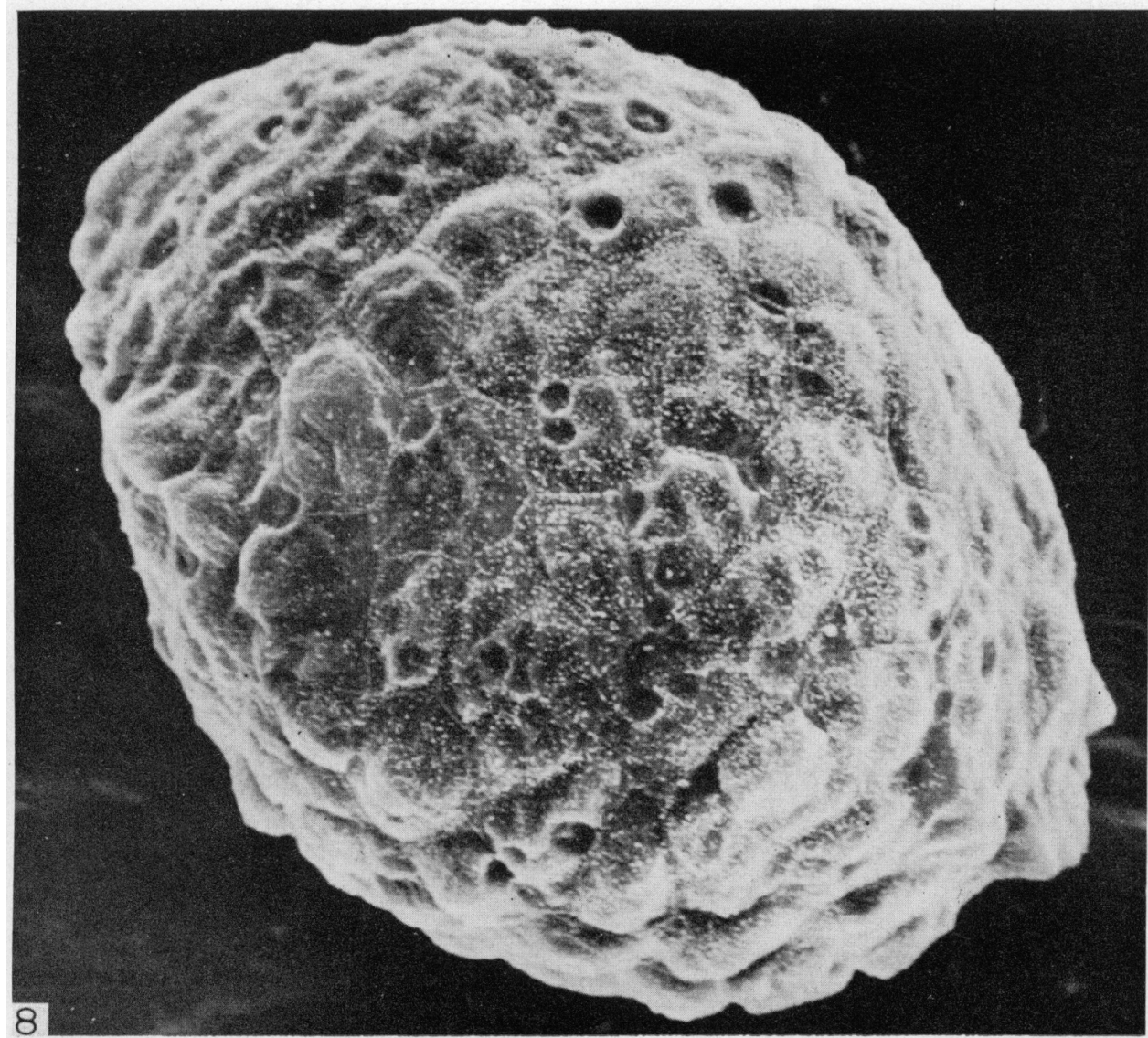

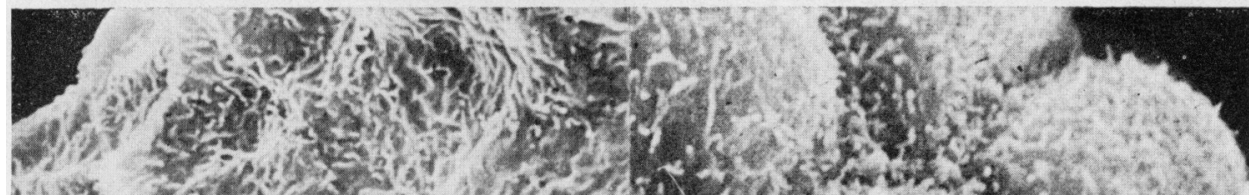

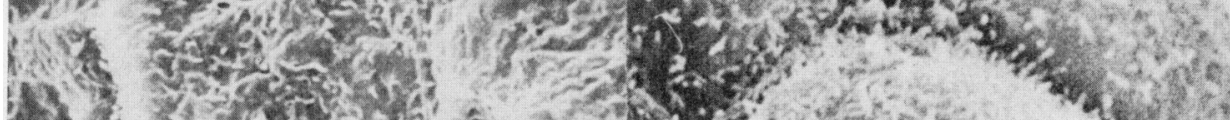
Q3 fr.

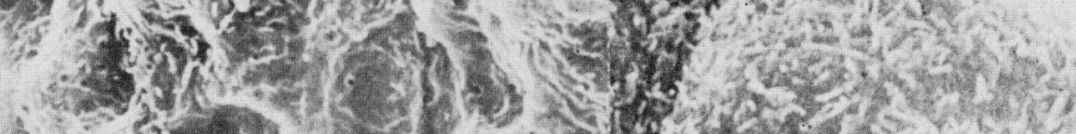

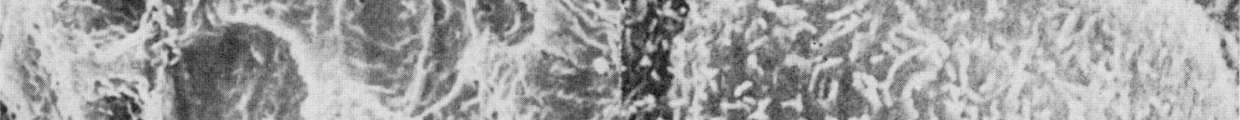
A. $3 x$ a

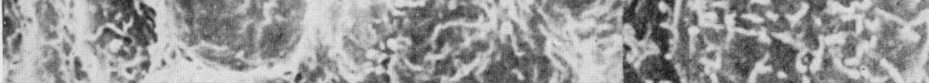

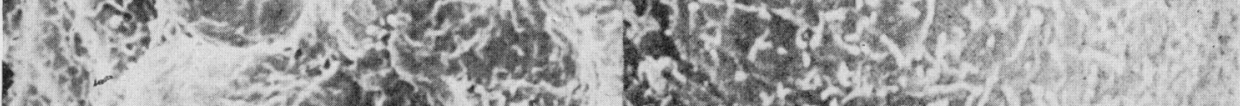

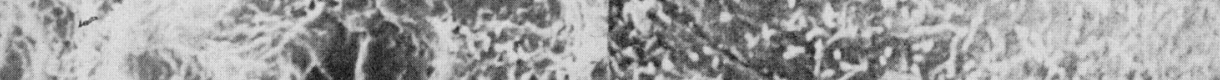

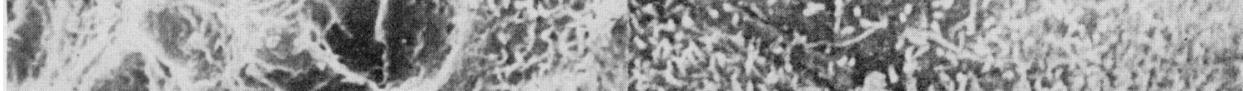

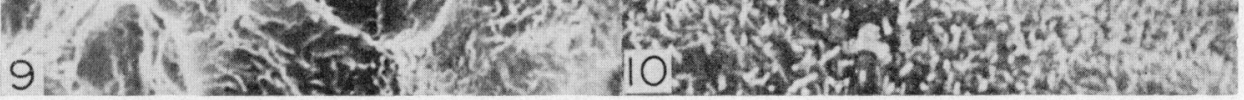




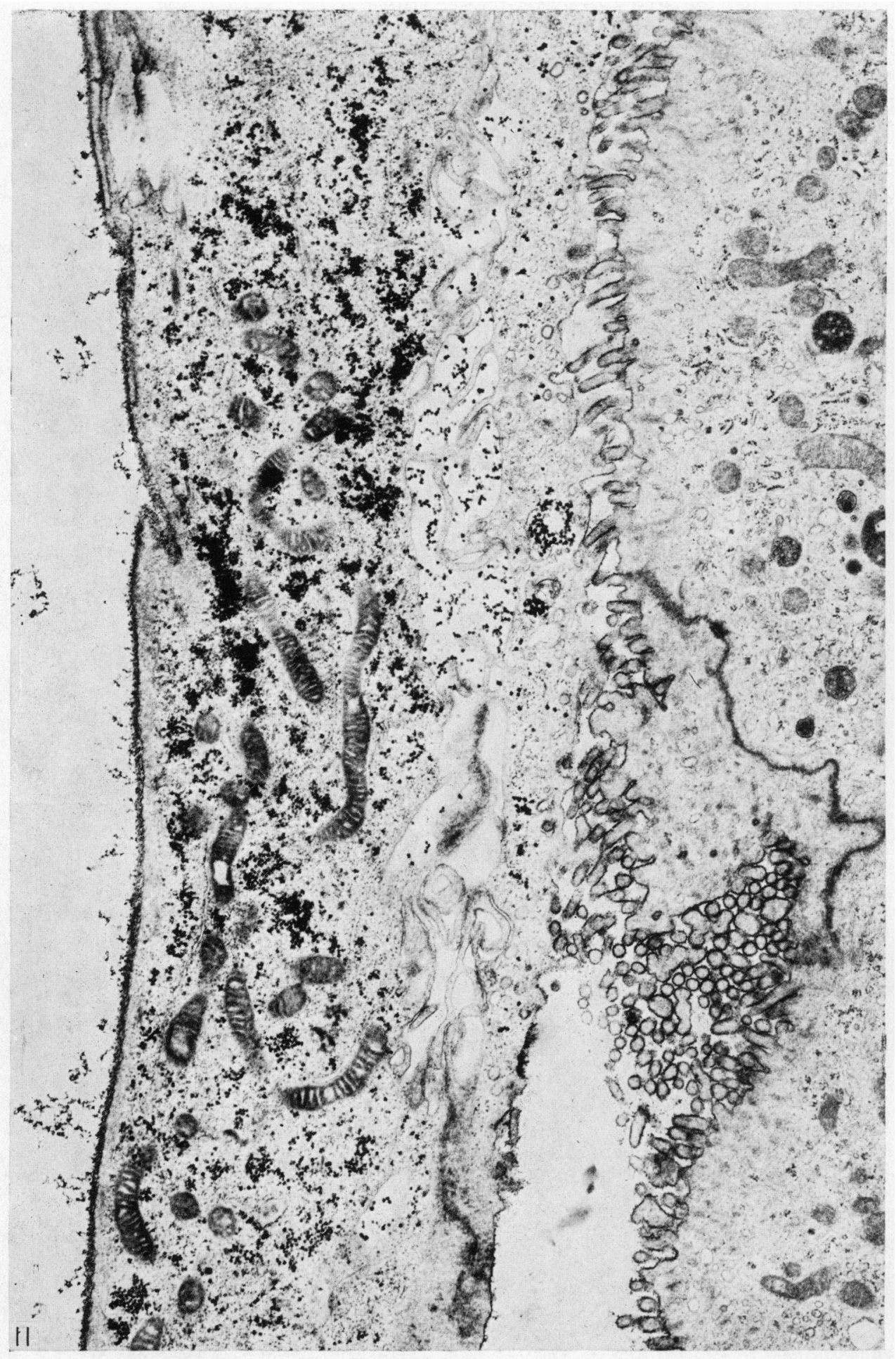




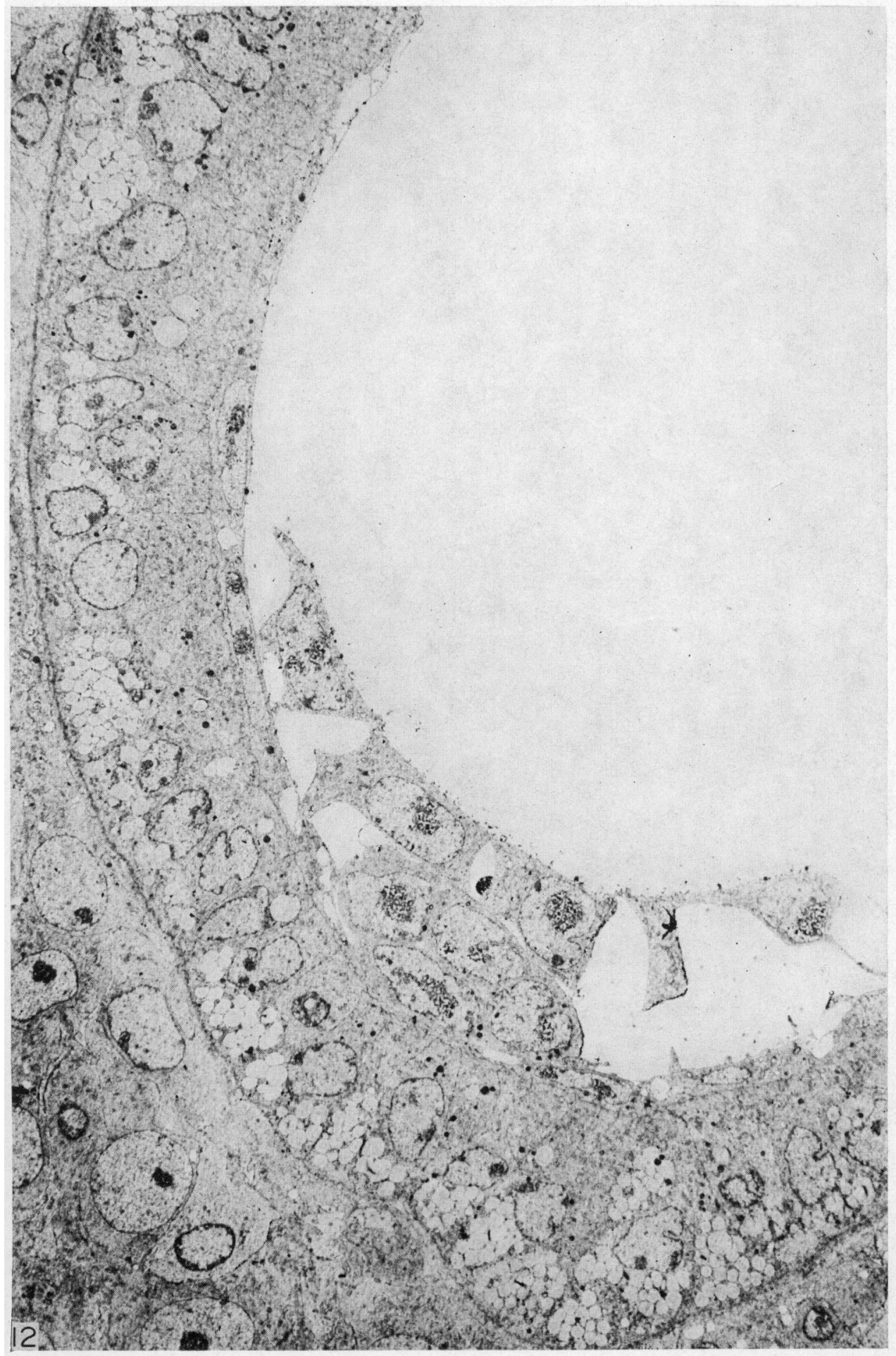




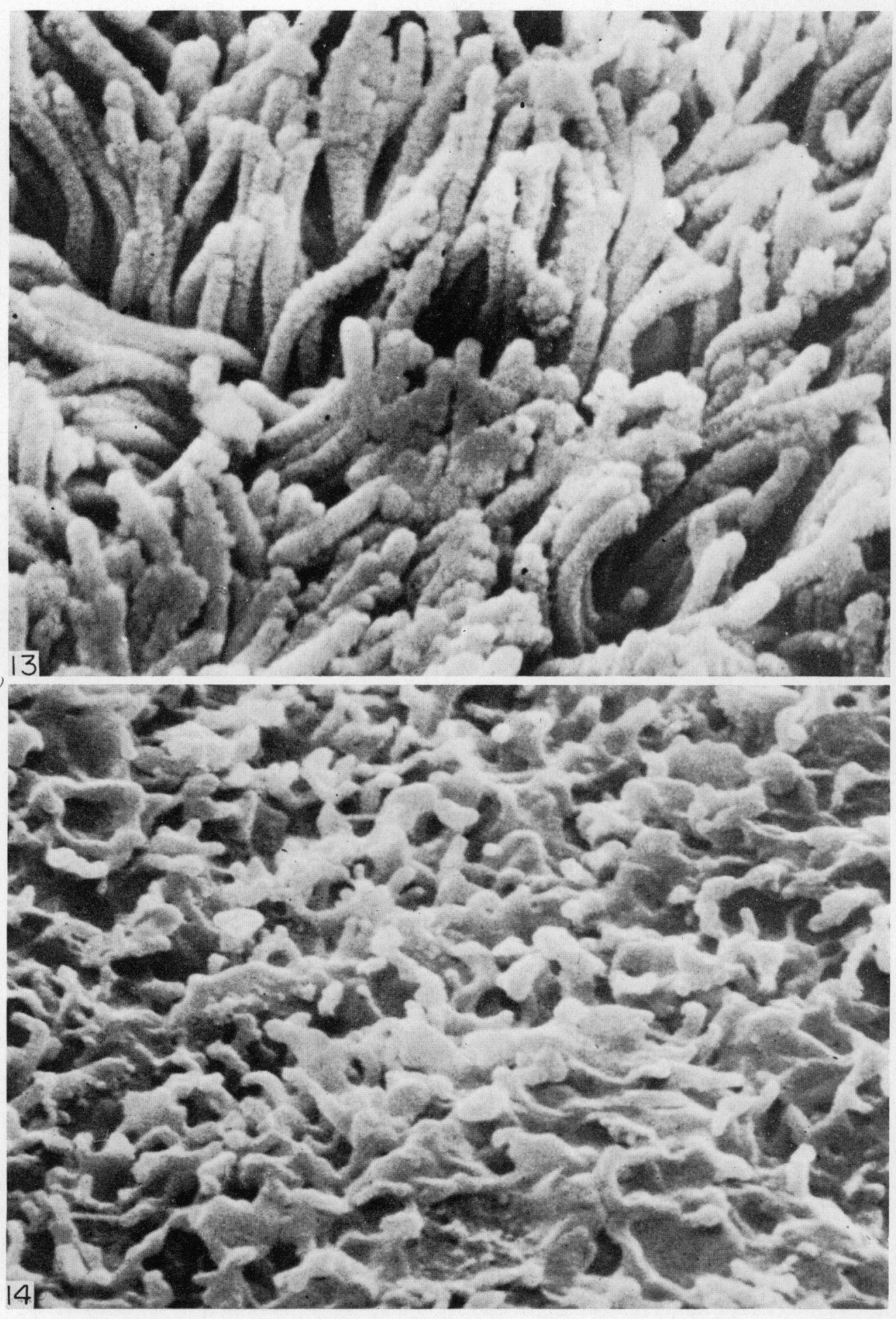




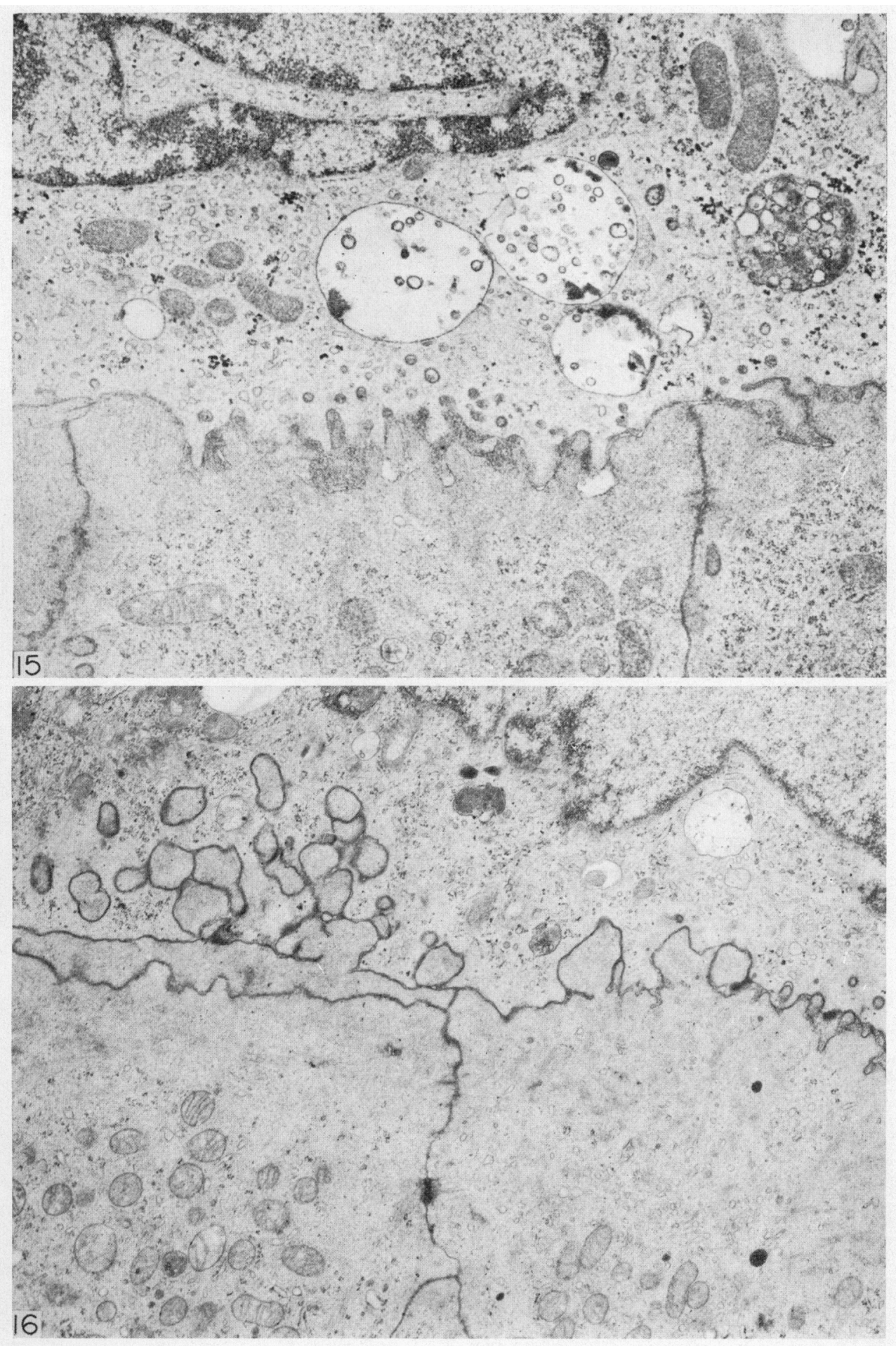


viability of the blastocyst (Weitlauf, 1971; Bergström \& Nilsson, 1972). But of course they may have other functions; they may, for instance, be sites of communication between the uterine epithelium and the blastocyst.

There are also changes in the cytoplasm of the trophoblast during the first week of the treatment with progesterone, but then the blastocyst seems to remain unchanged for at least another week having attained a steady state (Bergström, 1972a). This depression of activity is also indicated by other findings (Dupont, Duluc \& Mayer, 1970). It must be kept in mind when working with an experimentally delayed implantation that some days after ovariectomy are required for the blastocysts to 'calm down' to an inactive state.

The inactive blastocyst, examined after about 7 days of progesterone treatment, is closely attached to the uterine epithelium. The cytoplasm of its trophoblast cells (Pl. 3, Fig. 5) contains irregularly scattered ribosomes, a few rough endoplasmic membranes and the typical peculiar mitochondria with

\section{EXPLANATION OF PLATES 5 TO 9}

\section{PLATE 5}

FIG. 8. Blastocyst obtained from a mouse in delayed implantation treated with progesterone for 7 days following ovariectomy. The surface of the blastocyst has several crater-like imprints caused by the apical protrusions at the endometrial surface. (By courtesy of Dr S. Bergström.) $\times 1000$.

Fig. 9. Part of a blastocyst obtained from a mouse in delayed implantation treated with progesterone for 7 days following ovariectomy. The crater-like imprints are noticeable. (By courtesy of Dr S. Bergström.) $\times 3000$.

Fig. 10. Part of a blastocyst obtained from a mouse in delayed implantation treated with progesterone for 7 days following ovariectomy and given oestrogen $16 \mathrm{hr}$ before death. The trophoblast has a bulging surface with microvilli. No imprints of the endometrium are visible since the blastocyst was lying free in the lumen. (By courtesy of Dr S. Bergström.) $\times 3000$.

\section{PLATE 6}

Fic. 11. Part of an implantation site after progesterone treatment for 7 days after ovariectomy followed by oestrogen treatment $8 \mathrm{hr}$ before death. The trophoblast no longer lies closely apposed to the uterine epithelium. Glycogen is present in the cytoplasm of the trophoblast. The mitochondria of the trophoblast are dense and compressed compared to those of the uterine epithelium. $\times 6000$.

\section{PLATE 7}

Fig. 12. Part of an implantation site after a progesterone treatment for 7 days after ovariectomy followed by oestrogen treatment $16 \mathrm{hr}$ before death. The blastocyst has now attached to the uterine epithelium. The border between the trophoblast and the uterine epithelium is hardly visible. Some embryoblasts are observed. $\times 8000$.

\section{PLATE 8}

Fig. 13. Luminal surface of the uterus from a rat early on Day 4 of a normal pregnancy. The specimen was obtained during the period of progesterone dominance. The regular microvilli are demonstrated. $\times 10,000$.

Frg. 14. Luminal surface of the uterus from a rat late on Day 5 of a normal pregnancy, the approximate time of blastocyst attachment. The microvilli have disappeared and the surface has an undulate appearance. $\times 10,000$.

\section{PLATE 9}

Fig. 15. Part of a 'delayed' blastocyst in the uterus of a mouse after 7 days of progesterone treatment following ovariectomy and $16 \mathrm{hr}$ after an injection of oestradiol. Several multivesicular bodies of different types are present in the trophoblast. Some vesicles seem to have released their contents. $\times 8000$.

Fig. 16. Part of a 'delayed' blastocyst in the uterus of a mouse after 7 days of progesterone treatment following ovariectomy and $32 \mathrm{hr}$ after an injection of oestradiol. A narrow layer of a dense substance has appeared at the trophoblast-epithelial border. Small parts of the epithelial cytoplasm are situated deep in the trophoblast. $\times 6000$. 
spherical excavations (Stern, Biggers \& Anderson, 1971). This ultrastructure indicates that the trophoblast is metabolically rather inactive; a similar conclusion has been reached also by the use of other techniques (Menke, 1972).

The inactive state of these blastocysts is probably maintained by several circumstances. For instance, a lack of some critical nutrient (Daniel \& Krishnan 1969) - suggested by the paucity of secretion around the blastocyst-or the presence of an inhibitor in the scanty amount of secretion present (Weitlauf, 1972, 1973). Further, the properties of the cell membranes might be important: their ultrastructure implies a state characterized by a low degree of intercellular communication. The dark deposits at the border membranes (Pl. 3, Fig. 5) suggest this since an increased number of these deposits might indicate an increased number of sites for calcium binding, resulting in decreased possibilities for intercellular communication (Oschman \& Wall, 1972).

During the first days following ovariectomy the trophoblast ultrastructure indicates intense cytoplasmic activity (PI. 2, Fig. 4), but it appears to become inactive later during the progesterone treatment. Thus, the mouse trophoblast is apparently able to repress its activity during the delay of implantation and to resume it again when oestrogen is given (Gulyas \& Daniel, 1969; Weitlauf, 1969).

The capability to stay inactive and then later to resume growth characterizes blastocysts from species normally exhibiting delayed implantation. It is not yet known whether delay can be induced in species without facultative implantation delay, for instance the hamster and the human, or whether these blastocysts are programmed to go on developing. We are currently tackling this problem.

\section{BLASTOCYST ACTIVATION}

Various ideas on the nature of blastocyst activation by oestrogen have been summarized and discussed by McLaren (1973). In general, oestrogen acts either directly on the blastocyst or indirectly by influencing some property of the endometrium (Smith, 1968; Gulyas \& Daniel, 1969; Unger \& Dickson, 1971; Weitlauf, 1973). At present, I favour the latter possibility.

Eight hours after the injection of oestrogen the blastocyst has become separated from the endometrium by a newly produced uterine secretion. An active blastocyst rinsed out of the uterus and observed in the scanning electron microscope (Pl. 5, Figs 9 and 10) differs from an inactive one by having a bulging smooth surface with regular microvilli (Bergström, 1972b). The surface lacks endometrial imprints since the blastocysts now lie free in the lumen. The bulging appearance seems to be caused by an increase in volume.

Glycogen granules now appear in the activated trophoblast. Clusters of ribosomes form, and there is an increased amount of rough endoplasmic reticulum (McReynolds \& Hadek, 1972). Further, a transformation of the orthodox conformation of the mitochondria to the condensed type occurs (Pl. 6, Fig. 11). In the uterine epithelium, the content of the apical vesicles seems to be discharged into the uterine lumen.

The transformation of the mitochondria indicates increased oxidative phosphorylation (Hackenbrock, Rehn, Weinbach \& Lemasters, 1971) and, when taken together with many other findings (Weitlauf \& Greenwald, 1968; 
Dass, Mohla \& Prasad, 1969; Sanyal \& Meyer, 1972), implies an increased metabolic activity of the trophoblast. Since the uterine epithelium has started to secrete more actively, the blastocysts are perhaps stimulated by a decrease in a postulated inhibitory factor, or by increased availability of some critical nutrient in their environment of the secretion.

From the observations of several authors (Fridhandler, Wastila \& Palmer, 1967; Thomson, 1967) glucose appears to be a critical nutrient. When testing this hypothesis in vitro, it was found that as long as the medium was deprived of glucose the blastocysts were kept in a delay state, but when glucose was added they started to grow out on the support (G. Naeslund, in preparation). Similar results have also been obtained when testing various amino acids (Gwatkin, 1966). Other trigger mechanisms may also, of course, be involved.

\section{TROPHOBLAST ATTACHMENT}

Approximately 1 day after the injection of oestrogen the trophoblast attaches to the uterine epithelium (Pl. 7, Fig. 12). The initial apposition of the trophoblast and the epithelium is brought about mainly by the closure of the uterine lumen and to a lesser extent by an expansion of the blastocyst. In the mouse, attachment involves the whole of the outer surface of the cells, in contrast to some other species which first attach to the endometrium by trophoblastic knobs or projections (Steer, 1971). The early trophoblast-uterine epithelial contact sites are probably important for cellular communication and function perhaps to initiate embryonic development and/or to induce decidual cell transformation.

Little is known concerning the biochemical changes associated with blastocyst attachment. The sialomucins of the surface coat are probably changed, since there is a change in the surface charge of the blastocyst: the active blastocyst is less negative than the inactive one (Nilsson, Lindqvist \& Ronquist, 1973). This change is probably a result of intracellular changes in the trophoblast. However, extrinsic factors such as a change in the electrolyte concentration of the uterine secretion (Clemetson, Kim, Mallikarjuneswara \& Wilds, 1972; Levin, 1973) or an increase in the neuraminidase activity of the secretion might also be involved.

Blastocyst attachment is accompanied by changes in the configuration of the surface of the uterine epithelium. As seen with the scanning electron microscope, the regular microvilli disappear and the surface attains a more smooth but undulate appearance (Pl. 8, Figs 13 and 14).

The invasion of the trophoblast probably begins simultaneously with attachment as several ultrastructural features associated with invasion are already present at this stage.

\section{TROPHOBLAST INVASION}

A day and a half after the injection of oestrogen, the trophoblast is sometimes separated from the uterine epithelium by a very thin layer of a dense secretion (Pl. 9, Fig. 15). The cytoplasm of the trophoblast is observed to engulf fragments of healthy looking uterine epithelial cells (Pl. 9, Fig. 16). Several multivesicular bodies occur, and in the uterine epithelium the number of lysosomes 
seems to increase. At this stage, the amount of degrading enzymes has been shown by histochemistry to increase both in the trophoblast and in the epithelium at the site of implantation (Dickson, 1969; Bergström, 1970, 1972a; Smith \& Wilson, 1971); this accords with the ultrastructural findings.

The mechanism of the early invasion is as yet a matter for speculation. Perhaps the trophoblast releases enzymes that affect the epithelial cells or perhaps it induces an autolysis of the epithelium. Purely mechanical factors may also be important.

\section{IMPLANTATION in vitro}

Egg culture permits experimentation on the fertilized egg during its development to the blastocyst stage (Gwatkin, 1972). However, the technique usually fails for studies of further developmental stages, since the blastocyst becomes disorganized and grows out as a flat 'implant' on the floor of the culture chamber. Attempts to improve the technique have been made by letting the blastocyst grow on an endometrial explant (Glenister, 1966) or on reconstituted collagen ( $\mathrm{Hsu}, 1971,1972$ ).

Another improvement has been obtained by using a three-dimensional support, like a collagenous matrix (Jenkinson \& Wilson, 1970) or a mouse uterine horn maintained in organ culture (Grant, 1973). Both approaches permit proliferation of the trophoblast (trophoblast invasion) and early development of the embryonic disc, but later developmental stages are not reached. A principal difference between these two systems is that, in the first approach, blastocyst development can be examined without interference from maternal tissue, while in the second approach the interaction between the two components can also be studied. This means that the second approach is appropriate for experimentation on various control mechanisms, such as the hormonal induction of implantation and the influence of systemically administered embryotoxic substances. Since the mouse uterus in organ culture is probably not immunologically reactive, we now aim to find out whether or not a heterologous blastocyst - such as that of a hamster-will implant in the mouse uterus in vitro.

\section{ACKNOWLEDGMENTS}

This work was aided by a grant from the Swedish Medical Research Council (Grant No. 12X-70). Technical assistants: Mrs Marianne Ljungkvist and $\mathrm{Mr}$ Bengt Wieselblad.

\section{REFERENGES}

Bergström, S. (1970) Estimation of proteolytic activity at mouse implantation sites by the gelatin digestion method. F. Reprod. Fert. 23, 481.

BERGSTRÖM, S. (1972a) Histochemical localization of acid uterine aminoacylnaphthylamidases in early pregnancy and in different states of the mouse. F. Reprod. Fert. 30, 177.

Bergström, S. (1972b) Scanning electron microscopy of ovo-implantation. Arch. Gynäk. 212, 258.

BERGSTRÖM, S. \& NiLsSON, O. (1972) Ultrastructural response of blastocysts and uterine epithelium to progesterone deprivation during delayed implantation in mice. $\mathcal{F}$. Endocr. 55, 217.

Bergström, S. \& NiLsson, O. (1973) Various types of embryo-endometrial contacts during delay of implantation in the mouse. F. Reprod. Fert. 32, 531.

Blandau, R. J. (1971) The Biology of the Blastocyst. University of Chicago Press, Chicago.

Galarco, P. G. \& Epstein, G. J. (1973) Cell surface changes during preimplantation development in the mouse. Devl Biol. 32, 208. 
Glemetson, G. A. B., Kim, J. K., Mallikarjuneswara, V. R. \& Wilds, J. H. (1972) The sodium and potassium concentrations in the uterine fluid of the rat at the time of implantation. $\mathcal{F}$. Endocr. 54, 417.

Danier, J. C. \& Krishnan, R. S. (1969) Studies on the relationship between uterine fluid components and the diapausing state of blastocysts from mammals having delayed implantation. F. exp. Zool. $172,267$.

Dass, G. M. S., Mohla, S. \& Prasad, M. R. N. (1969) Time sequence of action of estrogen on nucleic acid and protein synthesis in the uterus and blastocyst during delayed implantation in the rat. Endocrinology, 85, 528 .

Drckson, A. D. (1969) Gytoplasmic changes during the giant cell transformation of blastocysts from normal and ovariectomized mice. $\mathcal{F}$. Anat, 105, 371.

Dupont, H., Dulua, A.-J. \& Mayer, G. (1970) Action de la progestérone et de l'oestrogène sur les divisions cellulaires des blastocystes en lethargie chez la ratte ovariectomisée. $C$. $r$. hebd. Séanc. Acad. Sci., Paris, 270, 2118.

Enders, A. C. (Ed.) (1963) Delayed Implantation. University of Chicago Press, Chicago.

Enders, A. G. \& Schlafke, S. (1967) A morphological analysis of the early implantation stages in the rat. Am. 7. Anat. $120,185$.

Enders, A. G. \& Schlafke, S. (1969) Gytological aspects of trophoblast-uterine interaction in early implantation. Am. J. Anat. 125, 1.

Finn, C. A. \& Malaren, A. (1967) A study of the early stages of implantation in mice. 7 . Reprod. Fert. 13, 259.

Fridhandler, L., Wastila, W. B. \& Palmer, W. M. (1967) The role of glucose in metabolism of the developing mammalian preimplantation conceptus. Fert. Steril. $18,819$.

Glenister, T. W. (1966) Organ culture and its combination with electron microscopy in the study of nidation processes. Excerpta Medica Int. Congr. Series 133. Proc. 5th Wld Congr. Fert. Steril., June $16-22$, p. 385.

Grant, P. S. (1973) The effect of progesterone and oestradiol on blastocysts cultured within the lumina of immature mouse uteri. F. Embryol. exp. Morph. 29, 617.

Gulyas, B. J. \& Daniel, J. G., JR (1969) Incorporation of labelled nucleic acid and protein precursors by diapausing and nondiapausing blastocysts. Biol. Reprod. 1, 11.

Gwatkin, R. B. L. (1966) Amino acid requirements for attachment and outgrowth of the mouse blastocyst in vitro. 7 . cell. Physiol. 68, 335.

Gwatkin, R. B. L. (1972) Chemically defined media for mammalian eggs and early embryos. In Vitro, $8,59$.

Hackenbrock, G. R., Rehn, T. G., Weinbach, E. G. \& Lemasters, J.J. (1971) Oxidative phosphorylation and ultrastructural transformation in mitochondria in the intact ascites tumor cell. 7 . Cell Biol. 51, 123.

Hsu, Y. (1971) Post blastocyst differentiation in vitro. Nature, Lond. 231, 100.

Hsu, Y. (1972) Differentiation in vitro of mouse embryos beyond the implantation stage. Nature, Lond. 239, 200.

Hubinont, P. O., Leroy, F., Robyn, G. \& Leleux, P. (Eds.) (1970) Ovo-implantation, Human Gonadotropins and Prolaction. Karger, Basel.

Humphrey, K. W. (1967) The induction of implantation in the mouse after ovariectomy. Steroids, 10,591 .

Jenkinson, E. J. \& Wilson, I. B. (1970) In vitro support system for the study of blastocyst differentiation in the mouse. Nature, Lond. 228, 776.

Lanman, J. T. (1970) Delayed implantation of the blastocyst: an exploration of its effects on the developing embryo. Am. 7. Obstet. Gynec. 106, 463.

LEvin, R. J. (1973) A critique on the relevance of membrane potentials to the mechanism of nidation. 7. Endocr. 58, 141.

LJungkvist, I. \& NiLsson, O. (1971) Ultrastructure of rat uterine luminal epithelium at functional states compatible with implantation. Z. Anat. EntwGesch. 135, 101.

Lober, B. L., Levy, E. \& Shelesnyax, M. G. (1967) Studies on the mechanism of nidation. XXXIV. Dynamics of cellular interactions during progestation and implantation in the rat. Acta endocr., Copenh. 56, 7.

MaLaren, A. (1971) Blastocysts in the mouse uterus: the effect of ovariectomy, progesterone and oestrogen. 7. Endocr. 50, 515.

McLaren, A. (1973) Blastocyst activation. In The Regulation of Mammalian Reproduction, pp. 321-328. Eds. S. J. Segal, R. Crozier, P. A. Corfman and P. G. Condliffe. C. C. Thomas, Springfield, Ill.

McReynolds, H. D. \& HADEK, R. (1972) A comparison of the fine structure of late mouse blastocysts developed in vivo and in vitro. F. exp. Zool. 182, 95.

Menke, T. M. (1972) Changes in mouse blastocyst carbon dioxide production as a function of time postcoitum in delay of implantation during lactation or following ovariectomy. Biol. Reprod. 7, 414 . 
NiLsson, O. (1972) Ultrastructure of the process of secretion in the rat uterine epithelium at preimplantation. F. Ultrastruct. Res. 40, 572.

Nilsson, O., Lindevist, I. \& Ronguist, G. (1973) Decreased surface charge of mouse blastocyst at implantation. Expl Cell Res. 83, 421.

Oschman, J. L. \& Wall, B. J. (1972) Calcium binding to intestinal membranes. F. Cell Biol. 55, 58.

Pollard, R. M. \& FinN, G. A. (1972) Ultrastructure of the uterine epithelium during the hormonal induction of sensitivity and insensitivity to a decidual stimulus in the mouse. 7. Endocr. 55, 293.

Potrs, D. M. (1966) The attachment phase of ovoimplantation. Am. F. Obstet. Gynec. 96, 1122.

Potrs, D. M. (1968) The ultrastructure of implantation in the mouse. F. Anat. 103, 77.

Poтts, D. M. (1969) The ultrastructure of egg implantation. In Advances in Reproductive Physiology, Vol. 4. Ed. A. McLaren. Logos Press, London.

Potts, D. M. \& Psychoyos, A. (1967a) Evolution de l'ultrastructure des relations ovoendométriales sous l'influence de l'oestrogène, chez la Ratte en retard expérimental de nidation. C. r. hebd. Séanc. Acad. Sci., Paris, 264, 370.

Potts, D. M. \& Psychoyos, A. (1967b) L'ultrastructure des relations ovoendométriales au cours du retard expérimental de nidation chez la Souris. C. r. hebd. Séanc. Acad. Sci., Paris, 264, 956.

Potts, D. M. \& WiLson, I. B. (1967) The preimplantation conceptus of the mouse at 90 hours post coitum. F. Anat. 102, 1.

Psychoyos, A. \& MANdon, P. (1971a) Scanning electron microscopy of the surface of the rat uterine epithelium during delayed implantation. F. Reprod. Fert. 26, 137.

Psychoyos, A. \& Mandon, P. (1971b) Etude de la surface de l'épithélium uterin au microscope électronique à balayage. Observations chez la ratte au 4 et au 5 jour la gestation. $C$. $r$. hebd. Séanc. Acad. Sci., Paris, 272, 2723.

RAsPe, G. (Ed.) (1970) Advances in the Biosciences 4. Schering Symposium on Mechanisms Involved in Conception. Pergamon Press-Vieweg, Braunschweig.

ReINIUs, S. (1967) Ultrastructure of blastocyst attachment in the mouse. Z. Zellforsch. 77, 257.

SANYal, M. K. \& MEYer, R. K. (1972) Deoxyribonucleic acid synthesis in vitro in normal and delayed nidation preimplantation blastocysts of adult rats. F. Reprod. Fert. 29, 439.

Sмгтн, D. M. (1968) The effect on implantation of treating cultured mouse blastocysts with oestrogen in vitro and the uptake of $\left[{ }^{3} \mathrm{H}\right]$ oestradiol by blastocysts. $\mathcal{F}$. Endocr. 41, 17.

Smith, D. M. \& Biggers, J. D. (1968) The oestrogen requirement for implantation and the effect of its dose on the implantation response in the mouse. $\mathcal{F}$. Endocr. 41, 1.

Smrth, M. S. R. \& Wirson, I. B. (1971) Histochemical observations on early implantation in the mouse. F. Embryol. exp. Morph. 25, 165.

STEER, H. W. (1971) Implantation of the rabbit blastocyst: the adhesive phase of implantation. 7 . Anat. 109, 215.

Stern, S. J. D., Biggers, J. D. \& Anderson, E. (1971) Mitochondria and eariy development of the mouse. F. exp. Zool. 176, 179.

TACHI, S., TACHI, C. \& LindNeR, H. R. (1970) Ultrastructural features of blastocyst attachment and trophoblastic invasion in the rat. F. Reprod. Fert, 21, 37.

Thomson, J. L. (1967) Effect of inhibitors of carbohydrate metabolism on the development of preimplantation mouse embryos. Expl Cell Res. 46, 252.

Unger, B. \& Dickson, A. D. (1971) Effect of cycloheximide and actinomycin D on the mouse blastocyst undergoing the giant cell transformation. F. Anat. 108, 519.

WARREN, R. H. \& ENDERs, A. C. (1964) An electron microscope study of the rat endometrium during delayed implantation. Anat. Rec. 148, 177.

WertLaUf, H. M. (1969) Temporal changes in protein synthesis by mouse blastocysts transferred to ovariectomized recipients. F. exp. Zool. 171, 481.

WeITLAUF, H. M. (1971) Effect of progesterone on survival of blastocysts in uteri of ovariectomized mice. 7. Endocr. 51, 375.

WeITLAUf, H. M. (1972) Comparison of the uptake and incorporation of amino acids by normal and delayed implanting mouse blastocysts in vitro. Anat. Rec. 172, 424.

Weitlaur, H. M. (1973) In vitro uptake and incorporation of amino acids by blastocysts from intact and ovariectomized mice. F. exp. Zool. 183, 303.

Weitlauf, H. M. \& Greenwald, G. S. (1968) Influence of estrogen and progesterone on the incorporation of ${ }^{35} \mathrm{~S}$ methionine by blastocysts in ovariectomized mice. F. exp. Zool. 169, 463.

Wong, Y. G. \& Dickson, A. D. (1969) A histochemical study of ovo-implantation in the mouse. $\mathcal{F}$. Anat. 105, 547.

Yoshinaga, K. \& Adams, C. E. (1966) Delayed implantation in the spayed, progesterone treated adult mouse. F. Reprod. Fert. 12, 593. 